\title{
The Mere Busybody: Autonomy, Equality and Standing
}

\author{
RUSSELl BINCH*
}

It is often believed that the application of standing principles has little bearing on the ideological constructs that have guided the development of public law. However, a few commentators have attempted to alter this belief by demonstrating that standing promotes an individual's capacity and right to further her or his personal autonomy, an ideal that is deep and pervasive in our culture. From this, they conclude that it is desirable to prevent public interest organizations from initiating litigation. While the insight that standing and autonomy are fundamentally connected is an important contribution, the conclusion - that this bars access for public interest organizations - is disappointing. It fails to recognize that autonomy is often furthered by interdependence, and that the interdependent ties found in public interest organizations are of particular importance for disadvantaged persons. When we reconceive autonomy through the lens of equality, our understanding of standing is radically altered.
Il est souvent admis que l'application des principes de qualité pour agir a peu d'influence sur les concepts idéologiques qui ont guidé le développement du droit public. Néanmoins. quelques commentateurs se sont efforcés d'alérer cette croyance en démontrant que la qualité pour agir met de l'avant la capacité individuelle et le droit de promouvoir l'autonomie personnelle, un idéal profondément ancré et prépondérant dans notre culture. Ils en concluent qu'il est souhaitable d'empècher les organisations d'intérêt public d'intenter un procès. Si l'idèe de qualité pour agir et l'autonomie sont fondamentalement reliées est une importante contribution, la conclusion qu'elle en interdit l'accès aux organisations d'intérêt public est décevante. Elle ne reconnaît pas que l'autonomie est souvent encouragée par l'interdépendance et que les liens d'interdépendance trouvés dans les organisations d'intérêt public sont d'une importance toute particulière pour les personnes désavantagées. Notre interprétation de la qualité pour agir est radicalement changée lorsque nous re-concevons l'autonomie dans l'optique d'égalité.

\section{TABLE OF CONTENTS}

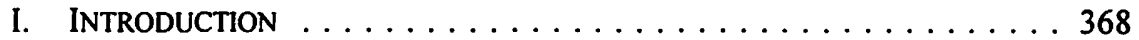

II. THE PRACTICAL FORMULATION $\ldots \ldots \ldots \ldots \ldots \ldots \ldots \ldots 369$

III. THE PHILOSOPHICAL FormUlation $\ldots \ldots \ldots \ldots \ldots \ldots \ldots . \ldots \ldots$

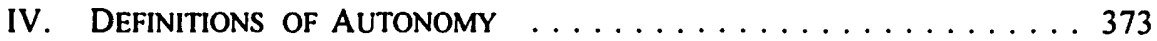

V. THE RELATIONSHIP BETWEen AUTONOMY

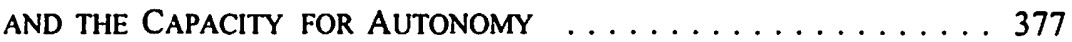

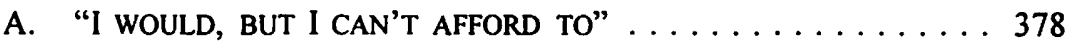

B. "I WOULD, BUT I FEAR THE CONSEQUENCES" . . . . . . . . 379

C. "I AM A SOCIALLY CONSTRUCTED INDIVIDUAL AND

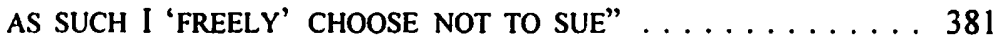

VI. QUESTIONS OF REPRESENTATIVENESS $\ldots \ldots \ldots \ldots \ldots \ldots \ldots 384$

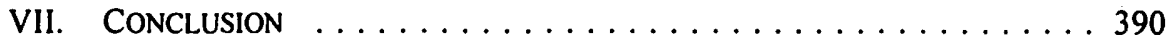

LL.M. graduate of the University of British Columbia. I would like to thank Robin Elliot, Phil Bryden, Susan Boyd, Claire Young and Kristin Häusler for their insightful comments, and the Canadian Commonwealth Scholarship and Fellowship Program for their financial support. Naturally, any errors are my own. This article is a revised chapter taken from my LL.M. thesis entitled Including the Excluded: A Minority Conception of Standing (University of British Columbia 2001) [unpublished]. 
Without an avenue to seek judicial redress for violation of their rights, the disadvantaged have only paper rights, without remedy, a situation fundamentally at odds with our sense of justice.'

\section{INTRODUCTION}

The judiciary believes that there are certain risks inherent in allowing people to initiate litigation on the basis of the infringement of third-party rights. The role of the public interest standing doctrine is to provide a safeguard (in the realm of public law) against these risks. ${ }^{2}$ One danger is that third parties may overburden court resources by initiating litigation when they do not have the appropriate motive or interest in resolving the issues raised in adjudication. ${ }^{3}$ The public interest standing doctrine seeks to close the adjudicative door in the face of those who have no "personal attachment" to a case, so to enable scarce judicial resources to be allocated to individuals who bring "real" disputes. The unattached third parties are sometimes referred to as "busybodies" (at least by their critics; those who see them in a better light tend to call them "public interest litigants"), and the reasoning behind public law's decision to exclude them from its courts is known as "the busybody rationale." Although the busybody rationale had lain dormant for many years, it appeared to be injected with new life in the leading authority on public interest standing in constitutional law: Canadian Council of Churches v. Canada (Minister of Employment and Immigration).

It would be disastrous if the courts were allowed to become hopelessly overburdened as a result of the unnecessary proliferation of marginal or redundant suits brought by ... well-meaning organizations pursuing their own particular cases certain in the knowledge that their cause is all important. ${ }^{4}$

However, the busybody rationale has not been widely accepted. In an attempt to boost its popularity, the rationale has undergone a makeover. Recently, commentators have contended that it not only protects the practical, but also the philosophical. The rationale is believed to safeguard one of our most intoxicating ideals - personal autonomy. In the ideological realm of autonomy, the private litigant is the benevolent sovereign, the public interest litigant the trespasser, or the malevolent dictator. In presuming that its own conceptions of the social good life are to be given absolute preference over those conceptions that we, as private individuals harbour, the public litigant denies the respect that should be accorded to us as rational, individual decisionmakers. When we recognize the importance of our capacity to act autonomously, we need a law that will rigorously protect it. We need a standing doctrine that prioritizes

Canadian Disability Rights Council \& Women's Legal Education and Action Fund, Canadian Council of Churches v. Canada (Minister of Employment and Immigration) (1991), [1992] 1 S.C.R. 236 (Intervener's factum at para. 82) [hereinafter LEAF factum; when referring to the organizations in the following text, I will simply refer to Women's Legal Education and Action Fund, hereinafter LEAF].

2 These risks are summarized by Le Dain J. in Finlay v. Canada (Minister of Finance), [1986] 2 S.C.R. 607, 33 D.L.R. (4th) 321 [hereinafter Finlay cited to S.C.R.].

T.A. Cromwell, Locus Standi: A Commentary on the Law of Standing in Canada (Toronto: Carswell, 1986) at 168 [hereinafter Commentary on the Law of Standing].

[1992] 1 S.C.R. 236 at 252, 88 D.L.R. (4th) 193 [emphasis added] [hereinafter Council of Churches cited to S.C.R.]. 
our capacity for self-determination, and that ejects any entity whose priorities fail to mirror our own. This usually means denying access to the public interest litigant.

This idea has an immediate, intuitive appeal and has been labelled "the greatest strength of the busybody limit." I agree that according due respect to the private litigant's capacity as a rational decision-maker is important. Indeed, it is of fundamental importance. However, that does not lead me to support the exclusion of the public interest litigant on the basis that he or she may be a mere busybody, particularly when that litigant is representing the interests of disadvantaged persons. As we shall see, the busybody rationale is grounded, and is thus intelligible, within the context of certain normative assumptions that are then presumed to apply universally. The more we question the attractiveness of such assumptions, the more we may appreciate that in certain circumstances "one man's 'busybody' may be another's saviour." 6

\section{The Practical formulation}

Before we explore notions of personal autonomy, I should briefly summarize the orthodox formulation of the busybody rationale and its shortcomings. This formulation contends that the discretionary grant of public interest standing should guard against litigation addicts who simply initiate litigation for the adrenalin rush. However, as has been observed many times, the demands and practical costs of litigation would appear to encourage litigants initiating suits with no forethought - with no motivation to achieve a just result - to kick their habit. ${ }^{7}$ Scott eloquently ridicules this formulation

C.A.L. Caruana, A Neo-Conservative Approach to Standing in Charter of Rights Litigation (LL.M. Thesis, Osgoode Hall Law School 1995) at 112 [unpublished] [hereinafter $A$ Neo-Conservative Approach to Standing].

- Law Reform Commission of British Columbia, Report on Civil Litigation in the Public Interest (Victoria: Queen's Printer for British Columbia, 1980) at 61. In this article, I will be focusing exclusively on public interest standing under the Canadian Charter of Rights and Freedoms, Part I of the Constitution Act, 1982, being Schedule B to the Canada Act 1982 (U.K.), 1982, c. II [hereinafter Charter]. In doing so, I do not intend to give the impression that the doctrine is immune from criticism as it applies to administrative law (and possibly under the division of powers). Indeed, I believe that the general tenor of my analysis can be transposed from one form of public litigation to another. However, there may well be certain characteristic differences that distinguish administrative litigation from Charter litigation, and that may alter the imponance we attach to autonomy as we move from one to the other. For example, we may agree that administrative law has a more "personal" feel to it than constitutional law (in the sense that administrative litigation often involves specific, individualized circumstances and complaints). It may be that this characteristic of administrative law (if true) demands that the following analysis be modified, though I do not feel that we must reject it entirely.

"People are not keen to rush to the courts. It is in their interest to avoid the inconvenience and expense of litigation rather than to commence proceedings on trivial issues." (1. Zamir. The Declaratory Judgment (London: Stevens \& Sons, 1962) at 272.) As the Ontario Law Reform Commission has observed, "litigation presents the spectre of a lengthy, arduous ordeal, with an outcome that is uncertain. Consequently it is suggested that there is a strong impulse for individuals to avoid legal action." (Ontario Law Reform Commission, Report on the Law of Standing (Toronto: Publication Services, 1989) at 46 [hereinafter Report on the Law of Standing].) 
of the busybody rationale: "The idle and whimsical plaintiff, a dilettante who litigates for a lark, is a specter which haunts the legal literature, not the courtroom."

Professor Scott may be guilty of overstating his case. True, the significant private costs associated with litigation act as a substantial access barrier which would tend to diminish the number of trivial suits brought before the courts. But that does not necessarily lead to the conclusion that there is no such thing as a busybody. Indeed, the Supreme Court of British Columbia has deemed certain persons to be "troublesome litigants." However, such persons are just as likely to be private litigants asserting their own interests and rights, as they are to be public litigants: "[I]t seems unlikely, given the usual disincentives to litigation, that plaintiffs would be particularly likely to rush into litigation concerning minor public wrongs but be more restrained with respect to minor private ones." 10 Justice Reed once commented that she found it hard to accept "that a host of trivial issues will be brought before the courts by public interest groups. I note that private interest litigation is not without its fair share of triviality at times."

\section{The Philosophical formulation}

The arguments and counter-arguments of practicality have been well rehearsed, and the debate, for now, appears to have reached an impasse. However, the busybody rationale appears to have found a new champion for its cause. Contemporary commentators have reformulated the busybody rationale, asserting that a restrictive granting of public interest standing respects the decision-making capacity of individuals affected by state action. Cromwell has argued that the standing doctrine should act as an epistemological device, enabling us to determine whose decision to sue or refrain from suing ought to bind other potential plaintiffs. ${ }^{12}$ This assertion begs the natural response, whose decision-making capacity should be employed as the ultimate, determinative gatekeeper of constitutional litigation? Cromwell's answer is that the decisions of "the plaintiff who is most directly and obviously interested" should be binding on others. ${ }^{13}$ If $A$ 's rights are infringed by B's actions, and A decides not to sue, then why should we grant $C$ standing to commence proceedings against $B$ arising out of B's infringement of A's rights? Craig contends that our natural reaction would be that "if the person directly affected [A in our example] does not choose to challenge the act then no-one should be able to do so"; "14 "there may well be cases in which the interest which the law chooses to protect are content with the situation. If this is so a stranger should not be allowed to raise a possible cause of invalidity." Is Craig argues

K.E. Scott, "Standing in the Supreme Court - A Functional Analysis" (1973) 86 Harv. L. Rev. 645 at 674.

From discussions with Professors Bryden and Elliot, Faculty of Law at the University of British Columbia.

Commentary on the Law of Standing, supra note 3 at 179.

Grant v. Canada (A.G.), [1995] I F.C. 158 at 197, 81 F.T.R. 195 (T.D.).

Commentary on the Law of Standing, supra note 3 at 171.

Ibid.

P.P. Craig, Administrative Law, 3d ed. (London: Sweet and Maxwell, 1994) at 514.

Ibid. at 509. 
that the notion of ultra vires is relative and depends upon the response of those "most directly and obviously interested" in the state action. ${ }^{16}$ There may be cases where the interests impinged upon are proximately related to the individual affected in a way that her choice whether to initiate litigation or not should be the only choice worth judicial consideration:

The exclusion of the busybody amounts to nothing more than an answer to the rhetorical question, "If the obvious plaintiff does not wish to sue, why should anyone else be allowed to do so?" ... The general rule is one of deference to the decision of the more obvious plaintiff. [The busybody rationale] is not so much a matter of who may sue, but of who decides who may sue. ${ }^{17}$

What Craig and Cromwell appear to be implicitly acknowledging is the worth of personal autonomy, individual self-determination and critical self-definition. ${ }^{18}$ If the individual chooses not to sue, then a well-meaning but bothersome public interest litigant should not be allowed to take up the cause. Otherwise that would belittle the rational decisions that the affected individual had made. We all nod assuredly. Selfdetermination. What can be wrong with that? If the obvious plaintiff does not wish to sue, why should anyone else be allowed to do so? Self-determination is important, I agree. But the banner-waving of such a politically correct notion tends to obscure some important definitional issues. What do we ultimately mean by such ambiguous terms as autonomy and self-determination? How do we know when the individual affected has made an autonomous decision not to sue? Before we examine these issues in greater theoretical depth, it is interesting to contrast a debate that occurred twenty years ago between two American doctrinal scholars on the issue of public interest standing. Their twists and turns make explicit some of the various underpinning normative assumptions they relied upon in their doctrinal enquiries.

Brilmayer threw down the gauntlet. ${ }^{19}$ She argued that standing should guarantee the realization of the affected parties' right to self-determination. The main thrust of her thesis was that "persons should not be able to assert the rights of others even assuming they are good representatives." ${ }^{20}$ To hold otherwise would devalue the standing doctrine as an epistemological device: "To abandon [the standing doctrine] would be, in effect, to say that it is not important to find out who is personally affected and what their wishes are."21 She acknowledged that this distrust of public interest advocacy stemmed from the value she attached to individualism. Individualist theories contend

In a similar vein, Bogart contends that a "plea that some illegality has occurred would not by itself justify recognition. We are content that some breaches may go unrectified if the victims of those breaches are otherwise satisfied not to enforce their rights or to bargain them away through settlement." (W.A. Bogart, "Standing and the Charter: Rights and Identity" in R.J. Sharpe, ed., Charter Litigation (Toronto: Butterworths, 1987) 1 at 3-4.) Commentary on the Law of Standing, supra note 3 at 171. Although some commentators have attempted to delineate these terms, for the purposes of this article, the constructs are so similar that they will be used interchangeably. Requirement" (1979) 93 Harv. L. Rev. 297 [hereinafter "The Jurisprudence of Article III"]. Ibid. at 310 [emphasis in original]. lbid. at 314. 
that the fundamental term of our association with each other is our respect for each individual's liberty to pursue her or his own interests. In so doing, individualism places considerable emphasis on non-intrusion in the moral evaluation of social interaction. Charles Taylor defines individualism as a theory that "affirms the self-sufficiency of man alone."22 This emphasis on individual self-sufficiency was made explicit in the reforms that Brilmayer proposed. She concluded that those who wished to protect the rights of under-represented groups (which she termed "third parties") "should be attempting to involve those persons in the judicial process," rather than coercing people to accept a representative to act on their behalf, even if that would be in their best interests. ${ }^{23}$ In other words, we should be striving to make people more independent and less interdependent.

Tushnet replied to Brilmayer's thesis a year later. ${ }^{24}$ Although he was mainly concerned with the practical realities of representative litigation, his response appeared to draw support from a non-individualist theoretical framework. He argued that litigants are more likely to succeed in litigation if they can draw upon the support of a "substantial, and substantially unified constituency." 25 In other words, certain sectors of our society may find their self-determination furthered by those "taking the lead in litigation" due to the empowering reciprocation of material and moral support that takes place between members of the constituency, and between the constituency and its representatives. Indeed, if a minority litigant attempts to go to court without the supportive ties of the constituency, she may become discouraged from articulating her challenge. ${ }^{26}$ This non-individualist understanding of self-determination emphasizes the importance of interdependence - of ties of commonality - as the means of realizing personal autonomy. It seeks to comprehend the interrelationship of group interdependence and freedom.

What these introductory comments demonstrate is that the mere assertion of the need to respect the self-determination and autonomous capacity of the individual does not bring to a close discussions about whether the public interest litigant has a legitimate role to play in adjudication. Autonomy, as an ideological construct, is capable of demanding both the restriction and extension of access for the public interest litigant. If the invocation of autonomy is to be a meaningful addition to the literature on standing (and I think it should be), then we cannot rest on its mere invocation alone. We must make some sense of autonomy.

2.3 "The Jurisprudence of Article III," supra note 19 at 321.

$24 \quad$ M.V. Tushnet, "The Sociology of Article III: A Response to Professor Brilmayer" (1980) 93 Harv. L. Rev. 1698.

is $\quad$ bid. at 1717 .

2. "[I]f the litigant is not honored in his or her hometown, it will be hard to sustain interest in the suit." Ibid. at 1718. 


\section{DEFINITIONS OF AUTONOMY}

As Raz comments, "The ruling idea behind the ideal of personal autonomy is that people should make their own lives. The autonomous person is a (part) author of his own life." ${ }^{27}$ Concepts of autonomy, self-direction and self-determination are therefore important elements in our understanding of "freedom." However, beyond such statements, the notion of autonomy is capable of yielding many different interpretations. One attempt to add greater concreteness to the ideal of personal autonomy contends that we are only acting autonomously if we are standing on our own two feet, isolated and protected from the threat of engulfment constituted by the collective or the community. We make our own decisions and we alone are responsible for them. West explains:

Because I am separate from you, my ends, $m y$ life, $m y$ path, $m y$ goals are necessarily my own. Because I am separate, I am "autonomous." 28

Every other discrete, separate individual - because he is the "other" - is a source of danger to me and a threat to my autonomy. I have reason to fear you solely by virtue of the fact that I am me and you are you. You are not me, so by definition $m y$ ends are not your ends. ${ }^{29}$

I shall term this notion of self-determination "individualism." It is a notion that has guided the development of constitutional traditions for some time. ${ }^{30}$ It focuses on boundaries as the means of comprehending and securing values of autonomy. As Professor Nedelsky observes, "the image of protective boundaries as essential to the integrity and autonomy of the self is deep and pervasive in our culture." 31

An individualist understanding of autonomy presumes "the existence of a particular kind of individual and a particular form of society." detached, self-sufficient, independent or atomistic individual, primarily engaged in pursuing his self-interest; a being who is fundamentally egocentric, living in competition and in fear of other individuals." ${ }^{33}$ It has been assumed that this notion of autonomy is valueless and objective - it is universal in that it applies an abstract understanding of personality. However, not everyone fits within the "universal" mould of individualism, and the reason behind this is one of social power. Casting autonomy in the language of competition is valid only if all members of society have the resources with which they can engage in the bargaining process. Casting autonomy in

J. Raz, The Morality of Freedom (Oxford: Clarendon Press, 1986) at 369 [hereinafter The Morality of Freedom].

R. West, "Jurisprudence and Gender" (1988) 55 U. Chi. L. Rev. I at 5 [hereinafter "Jurisprudence and Gender"] [emphasis in original].

Ibid. at 7 [emphasis in original].

J. Nedelsky, "Law, Boundaries, and the Bounded Self" in R. Post, ed., Law and the Order of Culture (Berkeley: University of California Press, 1991) 162 [hereinafter "The Bounded Self"].

lbid. at 168.

E. Comack, "Theoretical Excursions" in E. Comack, ed., Locating Law: Race/Class/Gender Connections (Halifax: Fernwood Publishing, 1999) 19 at 23.

S. Sevenhuijsen, Citizenship and the Ethics of Care: Feminist Considerations on Justice. Morality and Politics, trans. L. Savage (London: Routledge, 1998) at 12 [hereinafter Citizenship and the Ethics of Care]. 
terms of "boundary metaphors" is valid only if all members of society possess social advantages worth protecting through the construction of impermeable walls. For Nedelsky this is not the case:

The common law has been informed and shaped by particular conceptions of faimess, freedom, and progress. The "neutral" rules of the game correspond to a particular vision of good society which gives advantages to some players over others in systematic, if not perfectly predictable ways.... Freeing ourselves from misleading categories and false choices opens up the possibility for individual autonomy in the context of collectivity. ${ }^{34}$

In challenging the applicability of universal assumptions, feminism has also challenged the individualist notion of autonomy. ${ }^{35}$ It has argued that identity can be validly and autonomously expressed through interdependence and connection and has set out to reconceive the definition of identity and selfhood. Sevenhuijsen terms this reconception "the ethic of care." This ethic asserts that it is through supporting and sustaining other persons' capacities for autonomous decision-making that we will ultimately support and sustain our own:

In contrast to the atomistic view of human nature, the [ethic] of care posits the image of a 'relational self, a moral agent who is embedded in concrete relationships with other people and who acquires an individual moral identity through interactive patterns of behaviour, perceptions and interpretations. ${ }^{36}$

By emphasizing the development of autonomy through connectivity and interaction, the ethic of care is grounded in the transformative potential of dialogue, "and on the ability to reach judgement through consideration of different perspectives." ${ }^{.37}$ Rather than attempting to fit society within a universal, abstract template, the ethic of care reaches out to embrace different life experiences. Therefore, it goes some way towards respecting and promoting diversity and multi-dimensionality:

Connection, compassion and affectivity should be recognized as important sources of moral reasoning.... [T] he principle of non-intrusion [which is the basis of individualist thinking] is unsatisfactory as a primary moral principle, because it precludes the possibility of dependent people's needs becoming the focus for moral deliberation.... Instead of taking as its premiss self-sufficient, atomistic individuals, ethics should start from processes of connection and individuation. ${ }^{38}$

The adoption of an ethic of care does not lead us to abandon the ideal of autonomy. Our deep attachment to freedom (whatever our ethics) "takes its meaning and value from the presupposition of our self-determining, self-making nature: that is what

J. Nedelsky, "Reconceiving Autonomy: Sources, Thoughts and Possibilities" in A.C. Hutchinson \& L.J.M. Green, eds., Law and the Community: The End of Individualism? (Toronto: Carswell, 1989) 219 at 232-33 [hereinafter "Reconceiving Autonomy"]. 
freedom is for, the exercise of that capacity." ${ }^{39}$ Autonomy is a "goal which recognizes some true value of humanity, particularly, the honesty of subjective self-knowledge and the power of self-determination." ${ }^{\prime 40}$ The ethic of care also moves towards this goal. Nor should we devalue the important insight that respect for autonomy should play a vital part in the development of a sound public interest standing doctrine. However, if the idea of autonomy is not to act as a barrier to equality (and equal access) for disadvantaged groups, we need to understand how social power imbalances and autonomy interrelate. We need to reconceive autonomy so that we can combine "the claim of the constitutiveness of social relations with the value of self-determination."

We therefore need to reconceive autonomy through the lens of the ethic of care without belittling the importance of personal autonomy. Nedelsky has gone some way towards this reconceptualization. She emphasizes that "the capacity to find one's own law can develop only in the context of relations with others ... that nurture this capacity, and, second, that the 'content' of one's own law is comprehensible only with reference to shared social norms, values, and concepts." 42 "To be autonomous a person must feel a sense of her own power (which does not mean power over others), and that feeling is only possible within a structure of relationships conducive to autonomy.... Autonomy is a capacity that exists only in the context of social relations that support it." ${ }^{\prime 33}$ She argues that we must reinterpret and reclaim autonomy from individualism. The way to do so is to recognize that interdependence is an integral component of our ability to decide how to proceed in our own best interests:

If we ask ourselves what actually enables people to be autonomous, the answer is not isolation. but relationships - with parents, teachers, friends, loved ones - that provide the support and guidance necessary for the development and experience of autonomy... We see that dependence is not, as our tradition teaches, the antithesis of autonomy, but a literal precondition of autonomy, and interdependence a constant component of autonomy. ${ }^{44}$

The autonomy I am talking about does remain an individual value, a value that takes its meaning from the recognition of (and respect for) the inherent individuality of each person. But it takes its meaning no less from the recognition that individuality cannot be conceived of in isolation from the social context in which that individuality comes into being. The value of autonomy will at some level be inseparable from the relations that make it possible; there will be a social component built into the meaning of autonomy. ${ }^{45}$

"Reconceiving Autonomy," supra note 34 at 221.

S.G. Kupfer, "Autonomy and Community in Feminist Legal Thought" (1992) 22 Golden Gate U.

L. Rev. 583 at 592.

"Reconceiving Autonomy," supra note 34 at 221.

Ibid. at 224.

Ibid. at 239.

Ibid. at 225 .

Ibid. at 251 . There is debate about the extent to which this reconceptualization of autonomy as interdependence is an applicable model for both advantaged and disadvantaged groups in our society. D'Aoust argues that her autonomous dependency on others as a disabled person is no different from the autonomous dependency that shapes the lives of able-bodied people. "We live in a complex and inter-dependent society where almost no one is self-sufficient. We cannot expect anyone to become totally independent when our lives are built on the interactions and responses 
It is instructive to observe the manner in which autonomy has been conceived in other areas of public law. One such area is the resolution of apparent conflicts between the fundamental rights of expression and equality, for example in the constitutional review of provisions that prohibit the wilful promotion of racial hatred. In $R$. v. Keegstra ${ }^{46}$ the Supreme Court of Canada upheld the consitutionality of Canada's legislative prohibition against the promulgation of hate propaganda. ${ }^{47}$ In doing so, Dickson C.J.C. adopted reasoning that was sensitive to the interrelationship of group and individual in the furtherance of autonomy. Although he recognized that the threat of criminal sanctions tended to inhibit the realization of autonomy for those individuals whose expression it limits, Dickson C.J.C. laid greater stress on the process of selffulfillment that takes place within the context of supportive relationships:

A person's sense of human dignity and belonging to the community at large is closely linked to the concern and respect accorded to the groups to which he or she belongs.... The derision, hostility and abuse encouraged by hate propaganda therefore have a severely negative impact on the individual's sense of self-worth and acceptance. ${ }^{48}$

[S]elf-autonomy stems in large part from one's ability to articulate and nurture an identity derived from membership in a cultural or religious group. ${ }^{49}$

Chief Justice Dickson believed that these mutually supportive ties between individual autonomy and group membership constituted "a uniquely Canadian vision of a free and democratic society." $\$$

The task of reconceiving autonomy serves to highlight the difficulties experienced in accepting unthinkingly the thesis expounded by Craig and Cromwell. If autonomy is to be developed through social interaction, then the banner-waving of selfdetermination does not necessarily exclude interdependence and reliance on others. What does this mean when we transplant the ideology of autonomy-as-interdependence

of people to each other. Our individual lives cannot be isolated from the dynamic relationships of supply and demand, stimulus and response, need and service, production and consumption. We are all dependent." (V.D. D'Aoust, "Competency, Autonomy and Choice: On Being a Lesbian and Having Disabilities" (1994) 7 C.J.W.L. 564 at 567 [hereinafter "Competency, Autonomy and Choice"].) However, West appears to suggest that men prefer to further their autonomy through the medium of isolated individualism. "[M]en can connect to other human life. Men can nurture life. Men can mother. Obviously, men can care, and love, and support, and affirm life. Just as obviously, however, most men don't. One reason they don't, of course, is male privilege." ("Jurisprudence and Gender," supra note 28 at 71 .)

[1990] 3 S.C.R. 697 [hereinafter Keegstra].

As laid out in the Criminal Code, R.S.C. 1985, c. C-46, s. 319(2).

Keegstra, supra note 46 at 746.

Ibid. at 763.

Ibid. at 743. Lipset has employed this unique Canadian vision in his thematic comparative research into the socio-historical traditions of Canada and the United States. "The American social structure and values foster an emphasis on competitive individualism.... By contrast, the somewhat greater strength in Canada of the belief that a person's life is not necessarily subject to his or her control can plausibly be said to contribute to a more positive view of class ... action." (S.M. Lipset, Continental Divide: The Values and Institutions of the United States and Canada (Canada: Canadian-American Committee, 1989) at 170.) 
into the adjudicative realm? It could simply mean that the group financing of nominal plaintiffs in test cases is to be a welcomed mode of litigation. But what the reconception of autonomy-as-interdependence also implies is that according due respect to the rational capacities of individuals affected by the infringement of their Charter rights need not necessarily entail restricting judicial access to public interest litigants seeking standing. Indeed, we may positively encourage public interest litigants to litigate on behalf of an individual, ${ }^{51}$ if in doing so it is likely to further the interests of the individual affected. This positive encouragement of autonomy-as-interdependence becomes important when we begin to explore some practical obstacles to litigation that disadvantaged individuals affected by illegal state action may face. As we shall see, the new emphasis on interdependence as the means of furthering autonomy transforms the busybody rationale into a shield that protects and reinforces the status of organizations representing disadvantaged persons.

\section{THE RELATIONSHIP BetWEen Autonomy AND THE CAPACITY FOR AUTONOMY}

Craig and Cromwell have argued that the decision of the individual directly affected not to sue should usually be determinative of the question whether standing should be granted. If the individual directly affected is not heard to complain about state action, then his reaction is presumed to be one of contentment. The problem with this theory is that it can only be accepted once we abstract the individual directly affected from the power differentials that characterize social relations. Some people can exercise their autonomous capacity on a regular basis. Others struggle to do so. The fact that some find self-definition a relatively easy task, while others less so, is not because different people have differing amounts of autonomy. Rather, it is a consequence of the imbalance of social power. As Smith points out:

\footnotetext{
Having the ability to engage in autonomous decisionmaking does not guarantee that one will be able to implement or act on one's decisions. Social conditions can make that impossible.... To be an autonomous person, one must have a reasonable chance of acting on one's decisions. ${ }^{52}$
}

There exist many practical obstacles for disadvantaged persons in using the courts to remedy their social inequality - practical obstacles that can only be overcome through supportive group ties and interdependence. These obstacles are an inherent consequence of litigation itself, even when that litigation is meant to benefit disadvantaged groups by correcting the systematic malfunctioning of the democratic process (for example, when that process persistently discounts the interests of those

Particularly those litigants that resemble Tushnet's idea of a supportive constituency. I elaborate further on what is meant by a supportive constituency for the purposes of litigation later. For now, when referring to the "public interest litigant," I will substitute the term "public interest organization."

32 $\quad$ P. Smith, "Autonomy, Aspiration and Accomplishment: Some Steps and Barriers to Equality for Women" (1998) 9 J. Contemp. Legal Issues 257 at 275-76. 
groups). ${ }^{53}$ These obstacles mandate the recognition that the autonomy of disadvantaged persons can only be furthered (in the adjudicative sphere) if they act interdependently. As we shall see, Craig and Cromwell have not only misunderstood what autonomy actually means, they have misunderstood the degree to which certain disadvantaged persons can realize it. $^{54}$

\section{A. "I WOULD, BUT I CAN'T AFFORD TO"}

As lawyers we are familiar with the notion that the "most basic tenet of any constitutional society is the shared belief that by virtue of being citizens of a state, all persons are equal in the eyes of the law." ${ }^{\text {ss }}$ But commentators seem to forget that equality under the law comes at a price. Litigation is an expensive occupation, and few are willing to commence proceedings. Simply because some individuals have the resources to exercise their capacity for autonomous decision-making before the courts does not mean that we all have the same capacity to realize such self-direction. ${ }^{56}$ It cannot be said that we are realizing our true self-direction when we only have one choice, that being to decline to pursue disputes through the courts. As Raz observes, autonomy can only be exercised if the person has an "adequate range of options." 57 Autonomy cannot be assumed in conditions of no, or little, choice. Inactivity, therefore, does not necessarily mean contentment. ${ }^{58}$ If I would litigate had my financial

This legitimating theory of judicial review - that the courts can intervene when legislative decision-makers breach the duty to take into account the interests of all those that their decisions affect - is developed in J. Ely, Democracy and Distrust: A Theory of Judicial Review (Cambridge: Harvard University Press, 1980). The main principles are neatly summarized in W. Black, "Vriend, Rights and Democracy" (1996) 7 Const. Forum 126.

The following is not meant to be exhaustive; neither does it apply universally for each disadvantaged group.

D.P. Franklin \& M.J. Baun, "Introduction: Political Culture and Constitutionalism" in D. Franklin \& M. Baun, eds., Political Culture and Constitutionalism: A Comparative Approach (Armonk: M.E. Sharpe, 1995) $I$ at 5.

For example, studies have shown that women continue to face a significantly higher risk of poverty than men. In 1970, the Report of the Royal Commission on the Status of Women in Canada (Ottawa: Information Canada, 1970) concluded that: "(a) probably, in total, more women than men are poor, (b) there are specific groups of women, such as sole support mothers who are extremely poor, and (c) while discrimination and lack of supporting social institutions cause hardship among women at all income levels, they cause greatest distress among women who are poor" (at 309). When the National Council of Welfare readdressed this issue in 1990, they found that little had changed. Women and Poverty Revisited: A Report by the National Council of Welfare (Canada: National Council of Welfare, 1990). It is interesting to note that in its 1970 report, the Royal Commission drew the correlation between poverty and autonomy advocated here. "Poverty is to be without money, but it is also to have little hope for better things. It is a feeling that one is unable to control one's destiny, that one is powerless in a society that respects power" (at 311).

\section{The Morality of Freedom, supra note 27 at 372.}

D'Aoust argues this point not only in relation to financial resources, but also in terms of the array of factors that often serve to render access to the courts illusory: "The court system is so complex and inaccessible that very few women with disabilities ever become part of its process, despite being victimized by various acts and circumstances. The power imbalances are so institutionalized that even to get to court may be a victory. So the very few cases we know about are only a small indication of the need, the problem and the issues." ("Competency, Autonomy and Choice," supra note 45 at 578.$)$ 
circumstances been other than they are, then my decision not to litigate is not determinative of the issue of the relativity of ultra vires. We cannot merely assume that an absence of vocal complaint can only mean a positive affirmation of the infringement of my interests and rights. Rather, there exists a whole host of possibilities and probabilities, resources permitting and time constraints prohibiting that serve to question whether we should accord due respect to individual inaction in all cases. ${ }^{\$ 9}$

\section{B. "I WOULD, BUT I FEAR THE CONSEQUENCES"}

For the advantaged members of our society, autonomy and self-determination may well be akin to battle-cries. The individual voices his desire to "stand up and be counted," a need to have his exploits and suffering recognized by his peers. But such boldness, such freedom to pronounce your presence to the world, may not be held to the same degree by members of certain disadvantaged groups:

In order to fully understand the nature of the barriers to access which are imposed by a standing test based on individual harm, it is important to acknowledge that the circumstances of the disadvantaged include social, economic and physical vulnerability, isolation and fear of persons in authority or of sustained public visibility. Those conditions make it all the more difficult for them to think of confronting in litigation a governmental authority upon whose goodwill they may depend for income, chances of improvement, or even (in the case of refugees) their very lives. ${ }^{60}$

As LEAF alluded to in the passage above, immigrants and refugees may be anxious about the possible reprisals they may be subjected to should they bring an action against the government upon whose goodwill (so they may believe) their continued presence in the country depends. Again, inactivity does not necessarily mean contentment. The question whether there has been an exercise of autonomous capacity cannot be answered by examining merely whether the affected party initiates proceedings or not. Rather, this question must be placed in the context within which the inactivity occurred. In an extreme case, like that of refugees, the decision may

There is a way of lowering the screening costs of litigation without having recourse to public interest organizations: applying for legal aid. In the context of the Charter, the main source of such aid is channelled though the Court Challenges Program: a federally funded scheme that subsidizes challenges to federal law. However, "[m]any of the most important concerns of equality to disadvantaged groups arise in matters of provincial jurisdiction, for example, health and education. Equality cases in these areas would not be eligible for [legal aid]." (J. Mosoff, "Do the Orthodox Rules of Lawyering Permit the Public Interest Advocate to 'Do the Right Thing?': A Case Study of HIV-Infected Prisoners" (1992) 30 Alta. L. Rev. 1258 at 1264.) This is because there exists no analogous scheme that funds Charter challenges to provincial legislation. This creates problems of access in non-criminal matters, as civil matters tend to fall within the jurisdiction of the province. See Constitution Act, 1867 (U.K.), 30 \& 31 Vict., c. 3, s. 92(13), reprinted in R.S.C. 1985, App. II, No. 5. For general criticism of the legal aid system, see L. Addario, Getting a Foot in the Door: Women, Civil Legal Aid and Access to Justice (Ottawa: Status of Women Canada, 1998). 
ultimately rest on the choice of life over death. ${ }^{61}$ To defer to the decision of the individual affected in such and similar circumstances is to empty the term "selfdetermination" of all its intuitive appeal. ${ }^{62}$ Again, the absence of vocal complaint does not necessarily indicate a positive affirmation of the (otherwise) unconstitutional behaviour.

When LEAF intervened in Council of Churches, they argued that one of the advantages that public interest representation had to offer was the ability to advance the cause of the represented without the fear of consequences generated by selfidentification:

In order to obtain standing under the "private rights" test as presently interpreted, it is necessary for the individual to show that he or she possesses the characteristic of disadvantage relied upon. Selfidentification, in itself, may pose significant risks. As well, individual members of disadvantaged groups who advance equality claims on behalf of the group may be subject to backlash based on bigotry toward the group as a whole. Group standing to reinforce the equality rights of the disadvantaged would reduce individual members' visibility and vulnerability to reprisal and would offer at the same time the support of others who share the same risks and collective interests. In this fashion, the sharing of the disadvantage and the actions taken together about that disadvantage can provide a positive, empowering experience. It includes the individual rather than excludes her. ${ }^{63}$

In providing an avenue which enables choice to be freely exercised on an equal footing with the advantaged battle-criers (and in providing a concrete example of the transformative potential of autonomy-as-interdependence), the public interest organization is paying due respect to the aspirations of the individual. ${ }^{64}$

As Raz observes, "a choice between survival and death is no choice from our perspective (and we need not deny that [the refugees] may be very grateful that at least [they were] left this choice). An adequate range of options must therefore meet an additional separate condition. For most of the time the choice should not be dominated by the need to protect the life one has" (supra note 27 at 376).

These issues obviously do not apply solely in the context of immigration (though the consequences may be less severe than the loss of one's life). Gay men and lesbians may not wish to risk reprisals from work colleagues and family should they seek to challenge state action in which they have to identify their otherwise closeted sexuality. LEAF factum, supra note 1 at para. 50.

(4) In discussing a similar point raised during argument in League for Human Rights of B'Nai Brith Canada v. Canada (Minister of National Defence) (1991), 4 C.R.R. (2d) 177, 44 F.T.R. 166 (T.D.), Caruana argues that the fear of reprisal "still fails because a simple solution would be to allow the use of fictitious names. For example, the famous American case of Roe v. Wade was an abortion challenge by "Jane Roe." Jane Roe did not exist but was rather a pseudonym for a woman named Norma McCorby." (A Neo-Conservative Approach to Standing, supra note 5 at 123.) The use of fictitious names may be of some utility in protecting disadvantaged people from potential reprisals meted out by the hands of society at large. They are less likely to afford the same degree of protection when the source of the potential reprisal is your nearest and not-so-dearest. The employment of fictitious names may also be ineffective when a case generates publicity. The public's hunger to know the identities behind political intrigue and the media's willingness to feed that hunger can create an unbearable pressure for information that a fictitious name may not be able to withstand. The implications of such investigative journalism do not simply exist within the time frame of the trial. Those who are in a position of dependence upon the state, or others, may still suffer reprisals once the litigation has been concluded, and once any potential deterrence that 


\section{C. "I AM A SOCIALLY CONSTRUCTED INDIVIDUAL AND AS SUCH I 'FREELY' CHOOSE NOT TO SUE'}

A methodological critique of individualism asserts that we live within societies that are thickly self-constitutive. To understand human behaviour, one must look toward the "pervasive influence of social conditions in shaping individual values and political arrangements." ${ }^{\circ 5}$ Social conditions define the parameters within which one may be autonomous, within which one may make free choices. Thus, it is wrong to divorce the individual from the social context that determines how that individual's individuality is to be expressed. As Mendus puts it:

One consequence of this line of thought is to suggest that the language of autonomy, understood as the language of individual choice, of responsibility for self, and of voluntary obligation, has achieved exaggerated importance both in modern politics and, by implication, in modern philosophy. We are not simply striving individuals, but also passive recipients of obligations which we neither seek nor control. ${ }^{66}$

Nedelsky makes a similar observation:

We come into being in a social context that is literally constitutive of us. Some of our most essential characteristics, such as our capacity for language and the conceptual framework through which we see the world, are not made by us, but given to us ... through our interactions with others. ${ }^{67}$

Certain radical scholars have taken this insight one stage further in instances where there exist gross disparities of social power. For example, MacKinnon has argued that women are not merely thickly constituted by society. They are totally constituted by male societal norms. She therefore argues:

The perspective from the male standpoint enforces woman's definition, encircles her body. circumlocutes her speech, and describes her life. The male perspective is systemic and hegemonic.... Because it is the dominant point of view and defines rationality, women are pushed to see reality in its terms, although this denies their vantage point as women in that it contradicts at least some of their lived experience. ${ }^{68}$

MacKinnon believes that the social construction of "female" by men means that women's "complicity in their condition does not contradict its fundamental unacceptability if women have little choice but to become persons who then freely

contempt-of-court proceedings may offer has been dissipated.

M.J. Sandel, Liberalism and the Limits of Justice (Cambridge: Cambridge University Press, 1982) at 11 .

S. Mendus, "Strangers and Brothers: Liberalism, Socialism and the Concept of Autonomy" in D. Milligan \& W.W. Miller, eds., Liberalism, Citizenship and Autonomy (Aldershot: Avebury, 1992) 3 at $8-9$.

(7) "Reconceiving Autonomy," supra note 34 at 220.

6* C.A. MacKinnon, Toward a Feminist Theory of the State (Cambridge: Harvard University Press, 1989) 114 [hereinafter Toward a Feminist Theory]. See also R. West, "Feminism, Critical Social Theory and Law" [1989] U. Chic. L. Forum 59 at 87-89. 
choose women's roles." ${ }^{19}$ Thus, there exists no self to choose freely, apart from that which is socially determined to choose unfreely. "[W]omen, collectively oppressed under male domination, cannot freely choose their lives, even if they say their choices are freely made."70 If we listen to women who do not wish to upset the oppressive, marginalizing status quo, then we are not according respect for the articulation of their rational decision-making, but rather to the decisions men have made and have projected through the gendered vessel. ${ }^{71}$

I am slightly concerned about the implications of this radical critique. Rhode has warned that it runs the risk of "understating women's opportunities for social influence and social change," $" 72$ whereas Abrams has contended that the critique may encourage scrutiny of women's personal choices and detract from women's ability to make meaningful individual decisions. ${ }^{73}$

Kupfer has argued that MacKinnon's critique is somewhat softened when we acknowledge that autonomy can be furthered in an inderdependent fashion.$^{74}$ However, this does not mean that we should disregard MacKinnon's insights into how social construction limits the free choices that women can make. Indeed, Mill (often seen as the founding father of modern liberalism) carefully examined the ways in which social conventions reinforced by law constrained and confined women within a certain mould. ${ }^{75}$ And as D'Aoust reminds us, in a moving piece of self-reflection, it is not just women qua women-sole who suffer such fate: "As a lesbian, as a woman with disabilities, and as someone who could be seen as medically/legally incompetent, I have no choices." ${ }^{" 76}$ Society has excluded such disadvantaged persons from the multitudinous array of choices otherwise open to all, and thus has devalued their capacity for rational self-determination. As Réaume observes, once the possibility of such constraints on choice is acknowledged, "it is impossible to hold to the view that the individual's conception of her own welfare must be accepted uncritically. The real issue is how to distinguish legitimate from illegitimate constraints on choice." 77

69 Toward a Feminist Theory, ibid. at 124.

70 Kupfer, supra note 40 at 602.

" "If women are socially defined such that female sexuality cannot be lived or spoken or felt or even somatically sensed apart from its enforced definition, so that it is its own lack, then there is no such thing as a woman as such; there are only walking embodiments of men's projected needs." (Toward a Feminist Theory, supra note 68 at 119.)

72 D.L. Rhode, Justice and Gender: Sex Discrimination and the Law (Cambridge: Harvard University Press, 1989) at 85.

73 K. Abrams, "Ideology and Women's Choices" (1990) Geo. L. Rev. 761 at 779-83.

74 "Autonomy can be a transformative concept.... While the classic liberal concept of the individual does not seem full enough to account for women's differing vision for a society, the core values of autonomy (subjectivity, agency, self-determination) seem necessary for creation of freedom from subordination." (Kupfer, supra note 40 at 604.) J.S. Mill, "The Subjection of Women" in S. Collini, ed., On Liberty; with The Subjection of Women; and Chapters on Socialism (Cambridge: Cambridge University Press, 1989) 117.

"Competency, Autonomy and Choice," supra note 45 at 573.

D.G. Réaume, "The Social Construction of Women and the Possibility of Change: Unmodified Feminism Revisited", Book Review of Toward a Feminist Theory of the State by C.A. MacKinnon (1992) 5 C.J.W.L. 463 at 469. This is, of course, the real challenge when one adopts MacKinnon's critique of radical social construction: What is an illegitimate constraint on choice as opposed to 
The existence of any of these inhibiting circumstances may be difficult to prove or disprove (depending on where the burden of proof lies). However, the important point to stress (if litigation is to be open to all and treat all equally) is that an abstractly defined individual waving the banner of autonomy-as-independence cannot guard judicial access when so many persons will be seeking to further their autonomy in interdependent ways. The public interest organization, in providing a pool of experiences, a means of dialogue, sharing and empowerment (thus fulfilling some of the characteristics of the ethic of care) should give disadvantaged members the power to make autonomous decisions in the adjudicative sphere on an equal basis to those of individual advantaged members. As Evans J. observed in Sierra Club of Canada v. Canada (Minister of Finance), "members of vulnerable groups are, after all, often not in a position to defend their interests through litigation, and it is therefore quite appropriate that organizations that have an involvement with the issues should be allowed to litigate on their behalf." 78

However, this inevitably raises the question: how do we know that the organization will act so as to give disadvantaged individuals the power to make autonomous decisions? If we are to encourage public interest organizations to litigate on behalf of an individual (because we believe that in doing so we are likely to further the interests of the individual affected), then how can we be sure that the organization will be committed to that task? As Bowal puts it, "A representative organization ... bringing a case on behalf of its members generates concern about commonality of interest: how representative is the organization of the membership." 79 And when the organization deems to represent disadvantaged groups, we are concerned not only about the commonality of interest, but also whether the organization can be said to represent the diverse experiences of members of the group. How can we be sure that an organization is sensitive to the complex and diverse experiences of oppression of those it deems to represent, so as to promote the autonomy of all members in an effective manner? Should the representative status of an organization be the subject of judicial scrutiny in determining whether public interest standing is to be granted? Is such an enquiry amenable to judicial resolution? In the alternative, should representativeness be seen as a moral question to be resolved by the organization itself? These issues are important areas of concern. If we are to take the critique of autonomy-as-interdependence seriously, we must make sure that those litigants we listen to are able to further the autonomy of all individuals who may be affected by proposed litigation.

a legitimate one? I am not sure I know the answer and, in the interest of space, I certainly do not want to attempt to construct one here. However, what I do wish to re-emphasize is that the mere invocation of autonomy as a justification for a restrictive public interest standing doctrine tends to obscure these many difficult and concrete issues about what autonomy means in different people's lives.

78 Sierra Club of Canada v. Canada (Minister of Finance), [1999] 2 F.C. 211 at para. 53, 13 Admin. L.R. (3d) 280 (T.D.).

7" P. Bowal, "Speaking up for Others: Locus Standi and Representative Bodies" (1994) 35 C. de D. 905 at 917 [hereinafter "Speaking up for Others"]. 


\title{
VI. QUESTIONS OF REPRESENTATIVENESS
}

For Brilmayer, one of the crucial aspects of developing a sound public interest standing doctrine is the importance we attach to precedent. One of the great strengths of a restrictive public interest standing doctrine is that it prevents the results of litigation being imposed on directly affected individuals who are not before the courts. The binding effect of judicial pronouncements entails that we must be confident that we have the most representative of litigants before the courts. And there is no one more representative than the directly affected individual. According to Brilmayer:

\begin{abstract}
One of the best explanations of the case or controversy requirement [in Canadian law, this is comparable to a restrictive interpretation of public interest standing] may be the desire of the courts to ensure the accountability of representatives.... The case or controversy requirement guarantees that the individuals most affected by the challenged activity will have a role in the challenge. This guarantee should be seen as a minimal element of the legitimacy of a legal system which imposes legal burdens upon its members. At some point in the legal process affected individuals should have their day in court. $^{80}$
\end{abstract}

Although the critical insight Brilmayer offers is of great importance, the conclusions she draws from it are disappointing. After all, litigation brought by a directly affected individual will have the same binding effect as litigation brought by a public litigant. But a person who is directly affected by an issue relating to the law of mortgages is never asked to prove whether he is an able representative of all those Canadians who have mortgages. Yet his lawsuit denies all these individuals who have mortgages their day in court. It is important never to lose sight of the fact that disputes brought by private individuals will often house "public" values, interests that transcend the predilections of those bringing the challenge. As Bogart rightly concludes, "This is, after all, how law is produced." ${ }^{81}$ It may seem inequitable "that persons may be forced to accept consequences without having participated in the process determining those consequences," ${ }^{82}$ but it happens all the time, regardless of whether litigation is brought by an individual or a group: "The hermetic, bipolar structure of litigation means that private actors moving within it are simply unaccountable to any larger constituency standing outside the courtroom." ${ }^{83}$

The unaccountability of the individual litigant to the larger constituency is of particular concern when that constituency is a disadvantaged group. ${ }^{84}$ An interesting

"The Jurisprudence of Article III," supra note 19 at 310.

W.A. Bogart, "Understanding Standing, Chapter IV: Minister of Finance of Canada v. Finlay" Case Comment (1988) 10 Supreme Court L.R. 377 at 392.

Report on the Law of Standing, supra note 7 at 60.

A. Macklin, "Symes v. M.N.R.: Where Sex Meets Class" Case Comment (1992) 5 C.J.W.L. 498 at 516-17 [hereinafter "Where Sex Meets Class"].

For example, can we be certain that Nancy Rosenberg and Margaret Evans were truly representative of the lesbian and gay community when they challenged the definition of "spouse" in the Income Tax Act, R.S.C. 1985 (5th Supp.), c. 1, s. 252(4), that limited entitlement to spousal pension benefits to partners of the opposite sex? See Rosenberg v. Canada (A.G.) (1998), 38 O.R. (3d) 577,158 D.L.R. (4th) 664 (C.A.). It seemed obvious at the time that a litigation win for these 
case that appeared to question (albeit in a rather veiled fashion) the representative status of the individual initiating litigation was Symes v. Canada. ${ }^{85}$ In this case, a selfemployed woman brought an action in which, inter alia, she alleged that the restricted scope of deductible expenses contemplated by s. 18(1) of the Income Tax Act discriminated against her on the basis of her sex ${ }^{86}$ contrary to s. 15(1) of the Charter. She argued that the total amount of her child-care expenses should be deductible as a business expense under s. 18(1) on the basis that, had she not paid for child-care, she would not have been able to earn income from her business. The deductible expenses contemplated by s. 18(1) are available only to the self-employed. However, specific provision, under s. 63, had been made for parents (whether self-employed or as employees) to deduct child-care expenses up to a stipulated maximum per child. This deduction would have covered only thirty percent of the litigant's actual child-care expenses. The Supreme Court of Canada held that, although Symes had demonstrated how the issue of child-care had negatively affected women in employment terms, she had failed to prove that the burden of child-care expense was disproportionately placed upon women. ${ }^{87}$ Therefore, she had not proved that there had been an infringement of the right to equality under the Charter.

In seeking to reinforce his reasoning, lacobucci J. (writing for the majority) made repeated references to the economically privileged status of Symes in comparison with other women: "The appellant in this case belongs to a particular subgroup of women, namely, married women who are entrepreneurs. It is important to realize that her evidentiary focus was skewed in this direction"; 88 "I note that no particular effort was

two lesbians would act as a catalyst for the inclusion of lesbian and gay couples for all purposes under the $A C t$. Indeed, this has occurred, so that the $A c t$ now applies on the same basis to same-sex couples as it does to married and heterosexual couples. See Modernization of Benefits and Obligations Act, S.C. 2000, c. 12, s. 139(2). However, as Professor Young has ably demonstrated, "including lesbians and gay men as spouses for all purposes of the $\mathrm{ACt}$ is highly problematic." (C.F.L. Young, "Spousal Status, Pension Benefits and Tax: Rosenberg v. Canada (Attorney General)" Case Commentary (1998) 6 Can. Lab. \& Emp. L.J. 435 at 449.) See also C.F.L. Young, "Taxing Times for Lesbians and Gay Men: Equality at What Cost?" (1994) 17 Dal. L.J. 534 [hereinafter "Taxing Times for Lesbians and Gay Men"]. One problematic feature is that a failure to declare the fact that you are in a "conjugal" relationship with a member of the same sex is an offence. (Income Tax Act, s. 239(1)(a).) However, information provided to the Canada Customs and Revenue Agency is not kept completely confidential. This places lesbians and gay men who do not wish to identify themselves as such in an impossible position: "Either they will run the risk of their relationship becoming public knowledge, or if they are not prepared to do that, they will be committing an offence under the Act" ("Taxing Times for Lesbians and Gay Men," ibid. at 555). To the extent that such concerns can all be traced back to the decision in Rosenberg, are we content that the representative status of Rosenberg and Evans was never the subject of judicial scrutiny?

Symes v. Canada, [1993] 4 S.C.R. 695, 110 D.L.R. (4th) 470 [hereinafter Symes cited to S.C.R.]. Section 18(1)(a) provides as follows: "In computing the income of a taxpayer from a business or property no deduction shall be made in respect of an outlay or expense except to the extent that it was made or incurred by the taxpayer for the purpose of gaining or producing income from the business or property." Section 18(1)(h) provides that personal expenses are not to be counted as deductible expenses.

Symes, supra note 85 at 765 .

lbid. at 765-66. 
made in this case to establish the circumstances of single mothers"; 89 "there has been no attempt to involve the circumstances of low income Canadians in this Charter challenge." $" 90$ Justice Iacobucci appeared unwilling to give judgment for the applicant when the discrimination she apparently suffered was not representative of the experiences of most women. He explicitly relied upon a commentary on the Federal Court of Appeal's decision written by Professor Macklin. ${ }^{91}$ She argued that the hazards of Symes' claim for women far exceeded the potential benefits. If Symes were to win her lawsuit, it would do "little to facilitate the entry into the paid workforce by women who wish or need to do so but whose child rearing responsibilities confine them to the home." 92 Indeed, success for Symes could have had the effect of weakening calls for a comprehensive and accessible daycare program that would benefit all women. This was because success for her may have created the false impression "that the problem has been solved because a few businesswomen might be able to deduct their child care expenses."93

Why the representative status of the individual litigant is never a matter of concern in granting private interest standing is an illuminating question. ${ }^{94}$ It brings to light

\section{Ibid.}

Ibid. at 768 . These comments remind me of observations made by McIntyre. The directly affected individual "will put ' $a$ ' contending viewpoint before the court. But in a heterogeneous world, it seems misguided to imagine any or all directly affected challengers could or would wish to put all contending issues before the court even if they had the resources to do so." (S. Mcintyre, "Above and Beyond Equality Rights: Canadian Council of Churches v. The Queen" (1992) 12 Windsor Y.B. Access Just. 293 at 308.)

"Where Sex Meets Class," supra note 83. The decision of the Court of Appeal can be found at [1991] 3 F.C. 507,127 N.R. 348.

\section{lbid. at 515.}

Ibid. at 515-16. Young has indicated that the consequences of the case could have gone beyond political rhetoric: "Since the government has acknowledged that funding for child-care is limited, success for Ms. Symes and a consequent diversion of existing funds (or a limited amount of new funding) to only the self-employed might have been inappropriate. It could have served to reinforce the inequitable division of the subsidy, to the detriment of those who are already economically or socially disadvantaged." (C.F.L. Young, "Equality, Freedom and Democracy: Tax Law and the Canadian Charter of Rights and Freedoms" in S. Bottomley \& D. Kinley, eds., Commercial Law and Human Rights (Aldershot: Ashgate, 2002) at 7-8.)

It is also interesting to ask ourselves whether we would be so concerned about the representative status of a public interest litigant deemed to represent disadvantaged persons, if that litigant were an individual rather than an organization. In Finlay, supra note 2, the litigant, a person in need whose sole financial support was the allowance he received under the Manitoba Social Allowances $A c t$, R.S.M. 1987, c. S-160, was granted public interest standing to challenge the legality of deductions from his assistance payments that Manitoba was making to permit recovery of overpayments. Finlay contended that the deductions were contrary to Manitoba's undertaking (under the Canada Assistance Plan, R.S.C., 1985, c. C-1 [hereinafter CAP]) to provide assistance to any person in need in a manner that takes into account that person's basic requirements. He sought a declaration that deductions from an individual's social assistance to permit recovery of overpayments violated $C A P$, and, as a consequence, that the federal portion of the cost-sharing payments were illegal. He also sought an injunction to stop those payments as long as the provincial system of assistance to persons in need failed to comply with the undertakings imposed by $C A P$. When public interest standing was granted, Finlay's representativeness of persons in need in Manitoba was never questioned. This is slightly disconcerting, considering that the remedy sought by Finlay would actually make those residents of Manitoba in need more needy, as it would 
many of the assumptions we have unwittingly adopted in thinking about the role of litigation and precedent. As Chayes has argued, in a world dedicated to providing a framework for individual ordering, "the courts could be seen as an adjunct to private ordering, whose primary function was the resolution of disputes about the fair implications of individual transactions." 95 This has allowed orthodoxy to assert that litigation is a self-contained episode, even though it takes little critical reflection to be aware that such a picture has never been a truly valid description of civil litigation. The acceptance of this picture of adjudication has had the consequence that any entity other than the individual who wishes to initiate litigation so as to aid the expression of shared values is to be treated with the suspicion its unconventionality apparently deserves.

In its intervening factum in Council of Churches, LEAF gave some thought to what a test of representativeness would entail if standing were expanded to include the group representing disadvantaged persons:

In order to have such standing, the group would have to be composed primarily of those characterized by historic and continuing social disadvantage, and have among its objects the promotion of their equality. In any particular case, the group must demonstrate a proximity of connection between the issues raised and the disadvantage(s) characterizing those for whom it speaks. ${ }^{96}$

The demonstration of a group's proximity to the characteristic disadvantage suffered by members of the group is meant to address the issue of concreteness. Those groups whose interest in disadvantage is primarily abstract and academic are less likely to be granted standing.

Although this attempt to elaborate upon the nexus of representation is rather opaque, it is interesting to briefly review the attempts that LEAF itself has made to demonstrate a "proximity of connection" to the disadvantages characterizing those for whom it speaks. ${ }^{97}$ In its early days, LEAF appeared to present an elitist front. Carissima Mathen reports that, "Because LEAF's founding board and staff were white, middleclass professional women, there was legitimate skepticism of LEAF's ability to respond

serve to terminate the federal portion of assistance under $C A P$. I would speculate that Finlay's lawsuit was not well received by the community of which he was a member. Yet his ability to represent those who would be so adversely affected by his litigation was never considered. Indeed, it was only a matter of judicial consideration for the minority of the Supreme Court of Canada when the merits of the case were being argued. In holding that the deductions violated CAP, McLachlin J. refused to grant Finlay the relief he sought: "[A] blanket injunction against federal contributions to the cost of social assistance in Manitoba until the province complies with the minimum requirements of CAP is draconian and undesirable. It would cut off aid for a great many salutary programs, including child welfare." (Finlay v. Canada (Minister of Finance) (No. 2), [1993] 1 S.C.R. 1080 at 1120,101 D.L.R. (4th) 567.)

A. Chayes, "The Role of Judges in Public Law Litigation" (1976) 89 Harv. L. Rev. 1281 at 1285. LEAF factum, supra note 1 at para. 75.

Although the focus of LEAF's work is now centred on intervention rather than the initiation of litigation, the question of representativeness has always weighed heavily on LEAF's conscience. Indeed, in light of the important contributions that interveners have made in the equality jurisprudence of the Supreme Court of Canada, representativeness is of crucial concern for interveners as well those organizations hoping to gain standing. 
to and incorporate the interests and experiences of diverse women." 98 For instance, in 1987 the National Organization of Immigrant and Visible Minority Women of Canada questioned LEAF's sensitivity to the interests and perspectives of immigrant and visible minority women whose mother tongue was neither English nor French. ${ }^{99}$ How could LEAF bill itself as representative of all women's concerns, when its own board members were uniformly white, able-bodied and entrenched in the "have" sectors of society? This homogeneous elitism was confirmed by the analytical domination of a "sex-only" view of women's oppressions in LEAF's early caseload:

The equality analysis that LEAF advanced in earlier cases tended to emphasize the unity of women's experiences of oppression and the primacy of gender as a determining factor in these experiences. As a consequence, it tended to downplay, or in some cases to completely disregard, the significance of issues of race, class, sexuality, and disability as defining factors in women's subordination. ${ }^{100}$

Having gained credibility, LEAF began to act upon the criticisms that had been made about its representative status. According to Mathen, LEAF adopted a three-fold response: organizational, theoretical, and experiential. ${ }^{101}$ Organizationally, LEAF adopted a Diversification Policy in 1990. ${ }^{102}$ This policy commits LEAF to "actively pursuing a broad representation of women throughout the organization; recognizing the importance of inclusiveness and accountability in its administration and governance processes; and selecting and litigating cases that will involve and affect the greatest possible number and range of women." ${ }^{103}$ LEAF also created new board positions to communicate with marginalized women and encouraged women with diverse backgrounds to attend LEAF's public events. ${ }^{104}$ Theoretically, LEAF has attempted to incorporate into their legal work the conflicting insights that often accompany the recognition of women's difference, and "All case proposals must address the potential impact of a case on different groups of women." in Vriend v. Alberta ${ }^{106}$ highlights how LEAF has attempted to reflect the complexity and diversity of lesbian experience, and the importance of building "an expansive,

C. Mathen, "Introduction" in Women's Legal Education and Action Fund, Equality and the Charter: Ten Years of Feminist Advocacy Before the Supreme Court of Canada (Canada: Emond Montgomery Publications Limited, 1996) xv at xxi [hereinafter Feminist Advocacy Before the Supreme Court].

Recounted in S. Razack, Canadian Feminism and the Law: The Women's Legal Education and Action Fund and the Pursuit of Equality (Toronto: Second Story Press, 1991) at 57. Also, Robert Hough observed that "groups such as the Congress of Black Women, the Disabled Women's Network Canada (DAWN) and the National Organization for Immigrants and Visible Minority Women openly criticized LEAF, claiming the organization was elitist and ignorant of their plight." (R. Hough, "The Rise of LEAF" (1991) 15:3 Can. Law. 36 at 39 [hereinafter "The Rise of LEAF"'.)

A.S. Pellatt, "Equality Rights Litigation and Social Transformation: A Consideration of the Women's Legal Education and Action Fund's Intervention in Vriend v. R." (2000) 12 C.J.W.L. 117 at 132 [hereinafter "Equality Rights Litigation and Social Transformation"].

Feminist Advocacy Before the Supreme Court, supra note 98 at xxii.

Copy available from the National Office on request.

Feminist Advocacy Before the Supreme Court, supra note 98 at xxii.

"The Rise of LEAF," supra note 99 at 39.

Feminist Advocacy Before the Supreme Court, supra note 98 at xxii.

[1998] 1 S.C.R. 493, 212 A.R. 237. 
inclusive "feminine" ethical base for equality rights jurisprudence." 107 Finally, LEAF has "relied to an ever-increasing degree upon the insight and expertise of other women's organizations. In particular, LEAF has approached these organizations for assistance in forming the analysis around particular cases." ${ }^{108}$ In these three ways (organizational, theoretical, experiential), LEAF has taken note of the "varied ways in which the law actually operates in women's lives, which are not immediately apparent to those who make the arguments in court," ${ }^{109}$ and thus has demonstrated an increasing proximity to (or understanding of) the disadvantages suffered by those for whom it speaks.

Should the adoption of these inclusive strategies be another element structuring the exercise of the judicial discretion to grant public interest standing? In other words, is representativeness a moral question, a concern internal to the organization itself, or is it amenable to judicial scrutiny? Bowal has argued that the addition of a test gauging an organization's representative status would be an "unruly horse":

It would be a grievous miscalculation to devise a test where the extent of representativeness possessed by the organization is calibrated or scrutinized in each case. If some representativeness is demonstrated in order to establish "genuine interest), a court should not look further and deny standing on the basis that it could have been greater...

Evaluating the quality and quantity of representativeness will inexorably lead to impossible considerations about the age of the representative body, its objects, and formality. Normative judgments about what is urepresentative" or "not representative" can and will issue from all sides of any factual constellation. A representativeness test is also likely to be fraught with practical difficulties of proof. In the absence of reliable qualitative evidence, the exercise may quickly reduce to a nominally quantitative one that is subject to manipulation and arbitrary standards. ${ }^{110}$

Although I appreciate the concerns that Bowal raises, I think he has overstated his case. As he acknowledges, the courts already attempt to evaluate the genuine interest of a public interest litigant in the subject matter of the litigation. When the litigant is an organization, the courts have attempted to estimate the quality and quantity of representativeness possessed by that organization. For example, in Canadian Abortion Rights Action League v. Nova Scotia (A.G.), the Appeal Division of the Nova Scotia Supreme Court unanimously held that the public interest organization was genuinely interested in the issue of abortion: "the appellant, over the years, has been actively engaged in its stated objects concerning women's rights to 'safe, accessible abortions,'

107 "Equality Rights Litigation and Social Transformation," supra note 100 at 146.

tox Feminist Advocacy Before the Supreme Court, supra note 98 at xxii.

ios Ibid.

110 "Speaking up for Others," supra note 79 at 918-19 [footnotes omitted]. The fact that representativeness is a notion fraught with difficulties of proof is more pressing for my thesis than for Professor Bowal. For Professor Bowal, a representative body is one that is legally or contractually mandated to bring an action on behalf of economic interests, such as "liquor outlet licensees or expropriated landlords" (at 909-10). Obviously, organizations purporting to represent women, refugees, or other disadvantaged groups are not going to possess such a legally cognizable mandate. But a moral mandate to represent groups does not, by itself, render the representative less able or willing to serve the interests of that group or litigate effectively on its behalf. 
including applying for and obtaining intervener status before the Supreme Court of Canada." "II Evaluating the genuine interest of a public interest organization will usually involve a perusal of its activities. ${ }^{112}$ This need for a demonstration of historical involvement in the subject matter of the litigation may pose difficulties for those organizations that are in their formative stages, but it is difficult to imagine how genuine interest (and its constituent element of representativeness) could otherwise be tested. ${ }^{113}$ Representativeness, in the end, will be determined in part by judicial scrutiny, and in part (and probably the larger part) by organizational consciencesearching. Where the balance lies is a matter of discretion. But the exercise of that discretion must be sensitive to the barriers impairing access to justice for individual members of socially disadvantaged groups. ${ }^{114}$

\section{Conclusion}

The autonomy thesis promulgated by Craig and Cromwell is an important contribution to the standing scholarship. It forces us to appreciate that standing is not completely divorced from models of human association. What this article has hopefully demonstrated, if nothing else, is just how complex the theoretical assumptions that ground norms of legal procedure can be. Legal commentary which concentrates exclusively on the content of "substantive" norms is engaging in an exercise of folly and dishonesty. Our procedural norms must be analyzed just as closely using the critical tools that have been employed in other areas of law.

However, Craig and Cromwell have not lived up to this promise. The declaration of autonomy as a legitimating rationale of the public interest standing doctrine begs the

11' Canadian Abortion Rights Action League v. Nova Scotia (A.G.) (1990), 96 N.S.R. (2d) 284, 69 D.L.R. (4th) 241 at 249-50 (S.C. (A.D.)); affg (1989), 93 N.S.R. (2d) 197, 63 D.L.R. (4th) 680 (S.C. (T.D.)).

11. See Inshore Fishermen's Bonafide Defense Fund Association v. Canada (A.G.) (1994), 130 N.S.R. (2d) 121, 24 C.P.C. (3d) 108 at 117 (S.C. (T.D.)); Nolan v. Canada (A.G.) (1998), 14 C.P.C. (4th) 314 at 322-23 (Ont. Gen. Div.).

11 Unless it is not tested at all. But then form would win out over substance, and any organization could hurdle the access barrier of standing by a mere clause in their articles of association or constitution that describes their representative capacity.

114 Of course, we must attempt not only to clarify what is meant by "representation"; we must also be sensitive to what "disadvantage" is and by whom its effects are felt. We must continue to remind ourselves that disadvantage is a question of power and that inequality is the effect of the distribution of that power. Fortunately, our definition of disadvantage will largely correlate with the Supreme Court of Canada's interpretation of section 15(1) and the list of enumerated and analogous grounds of prohibited discrimination; see Andrews v. Law Sociery of British Columbia. [1989] I S.C.R. 143, 56 D.L.R. (4th) I [hereinafter Andrews cited to S.C.R.]; Egan v. Canada, [1995] 2 S.C.R. 513, 124 D.L.R. (4th) 609. In Andrews, Wilson J. cautions against divorcing analyzes of inequality from social reality: "I believe also that it is important to note that the range of discrete and insular minorities has changed and will continue to change with changing political and social circumstances.... It can be anticipated that the discrete and insular minorities of tomorrow will include groups not recognized as such today. It is consistent with the constitutional status of s. 15 that it be interpreted with sufficient flexibility to ensure the 'unremitting protection' of equality rights in the years to come" (at 152-53). I would contend that what tomorrow's interpretation of equality rights will need to ensure is a greater understanding of the intersectional nature of oppression. 
questions posed in this article: what exactly do we mean by "autonomy," and how can disadvantaged persons practically realize their autonomy within the adjudicative system? I have argued that autonomy can be reconceived in an interdependent fashion. This prevents the doors of the courtroom from closing in the face of public interest organizations at the mere mention of self-determination. I have also argued that disadvantaged individuals face practical difficulties (in terms of cost, the fear of reprisals, or lack of choice) in realizing their personal autonomy in an independent fashion. Therefore, the mere invocation of the contentment of the abstractly defined individual should not be universally applied with no understanding of the ways in which social power has closed off access to the adjudicative forum - a forum that is meant to act as a guardian of the interests of the disadvantaged. We must reconceptualize autonomy and comprehend the contextual relationship between autonomy and the capacity for autonomy. When we do so, we are faced with the difficult question of representative status and how we should go about measuring it. However, these questions are already being addressed both by the courts and the organizations themselves and both have begun to make tentative steps towards their successful resolution. Therefore, the invocation of self-determination (contra Craig and Cromwell) does little to hinder access for public interest organizations representing disadvantaged members of our society, and may, in fact, promote such access. 